\title{
PROCES LEGITYMIZACJI TRYBUNALU KONSTYTUCYJNEGO: PODEJŚCIE RELACYJNE
}

Rozważania problematyki legitymizacji instytucji prawnych, w tym Trybunału Konstytucyjnego, prowadzi się przede wszystkim z perspektywy ściśle prawniczej, skupiającej się najczęściej na formalnych procedurach wyboru sędziów. Legitymizację zabezpieczać mają przepisy prawne, które w swoich założeniach stoją na straży niezależności sądu konstytucyjnego od innych organów państwa, a także apolityczności zasiadających w nim jednostek ${ }^{1}$. Mimo to nierzadko sa przedmiotem ożywionej debaty, w której przedmiotem krytyki pozostaja głównie dwa zagadnienia: kryteria, jakie muszą spełnić kandydaci na przyszłych sędziów, a także sposób ich powołania ${ }^{2}$. W tym ostatnim zakresie podnoszone jest potencjalne uwikłanie polityczne sędziów, którzy moga orzekać „pod dyktando” wybierającej ich większości parlamentarnej ${ }^{3}$. Aby temu zaradzić, pojawiają się głosy nawołujące nie tylko do większej transparentności, ale wręcz jawnej deklaracji politycznej kandydatów ${ }^{4}$, szczególnie że wybór niektórych sędziów do Trybunału budzi emocjonalne reakcje ${ }^{5}$. Przybrały one na sile zwłaszcza w 2015 r., gdy dotychczasowe procedury wyboru zostały naruszone $e^{6}$.

Niewątpliwie więc problematyka powoływania do sądu konstytucyjnego z punktu widzenia jego legitymizacji jest wprawdzie stale rozważana i komentowana, ale jej prawnicza, a więc formalna, a nade wszystko silnie substancjalna perspektywa sprawia, że pozostaje niedostatecznie głęboko zbadana naukowo. Zakorzeniony w prawoznawstwie zdroworozsądkowy substancjalizm powoduje nierzadko, że instytucje prawne sa taktowane jako wyizolowane, statyczne byty (którym przypisywana jest określona tożsamość i spekulatywne cechy, np. racjonalność, neutralność itp. ${ }^{7}$, a nie jak podmioty uwikłane w różnorodne relacje zależności (w tym władzy), jakimi są w rzeczywistości ${ }^{8}$.

${ }^{1}$ Garlicki (1987): 97; Młynarska-Sobaczewska (2018): 43-62; Zajadło (2009): 129-144.

${ }^{2}$ Garlicki (2016): 2.

${ }^{3}$ Florczak-Wątor, Pach (2018): 22-42; Zoll (2016): 43-50; Czeszejko-Sochacki (2003): 124-31; Gromski (2009).

${ }^{4}$ Safjan (2016):36. Procedura wysłuchań publicznych kandydatów na sędziów w Polsce istnieje, ale rozwija się powoli i nie jest zadowalająca, zob. Bojarski (2007), (2010), (2018): 75-91.

${ }^{5}$ Siedlecka (2006a); Siedlecka (2006b); Zajadło, Koncewicz (2015).

${ }^{6}$ Rzetelna, prawnicza analiza: Łętowska, Wiewiórowska-Domagalska (2016): 79-93.

${ }^{7}$ Warczok (2013): 48.

8 Bourdieu (1988b): 155. 
Należy jednak przy tym wyraźnie zaznaczyć, że proponowana tu analiza nie tyle jest konkurencją wobec ujęć prawoznawczych, ile ich socjologicznym uzupełnieniem - zaznaczeniem tych społecznych aspektów funkcjonowania Trybunału, które dotąd nie były należycie naświetlone.

\section{TRYBUNAŁ KONSTYTUCYJNY JAKO PRZESTRZEŃ SPOŁECZNA}

W niniejszym artykule legitymizację będziemy zatem widzieć szerzej nie tylko jako formalna gwarancję bezstronności (sformułowanie odpowiednich przepisów i skonstruowanie prawniczych narzędzi ${ }^{9}$ ), ale jako długotrwały proces, który zapewnia uzasadnienie istnienia tej instytucji - uznanie, szacunek, zaufanie. Dokonuje się on niejako przez zawierzenie, że instytucja ta jest zdolna zapewnić neutralność w rozstrzyganiu sporów i ochronę wartości o uniwersalnym, publicznym charakterze ${ }^{10}$. Jeśli tak rozumiany proces się dokona, dochodzi (w mniejszym bądź większym stopniu) do rzeczywistej legitymizacji, czyli „zaprzeczenia” władzy, a precyzyjniej, zachodzi społeczne nierozpoznanie tego, co władza oznacza, a więc arbitralności, partykularności, własnego interesu, uzurpacji, siły, przemocy. Partykularyzmy ulegaja uniwersalizacji, sama instytucja zaś jawi się jako autonomiczna, niezależna od nacisków i wpływów ${ }^{11}$. W naszej analizie koncentrujemy się - co ważne na samej strategii legitymizacji TK, dokonywanej przez określony wybór sędziów (posiadających takie, a nie inne cechy społeczne) przez poszczególne partie polityczne.

Podążając za paradygmatem relacyjnym ${ }^{12}$, traktujemy Trybunał topologicznie jako rodzaj przestrzeni społecznej, zlokalizowanej na przecięciu kilku światów społecznych, z których wywodzą się sędziowie (prawo, ale też akademia, administracja, polityka) wyposażeni w konkretne cechy społeczne (tj. stopień naukowy, wykonywany zawód prawniczy, pełnienie w przeszłości funkcji poselskiej, członkostwo w radzie legislacyjnej itp.), określane - w przyjętej

9 Tak czynią klasyczne ujęcia prawne, traktujące legitymizację jako uznanie dla abstrakcyjnych, bezosobowych reguł jako podstawy obowiązywania władzy, która jest nimi związana; czy też podporządkowanie się racjonalno-prawnemu systemowi i uczynienie zadość jego procedurom. Zob. Weber (2002): 160 .

10 Dębska (2015): 24-25.

11 Zob. Bourdieu (2015): 130-133; 622-624. O tak rozumianym procesie w przypadku polskiego sądu konstytucyjnego zob. Dębska (2015).

12 Paradygmat relacyjny czy też relacjonalizm, traktowany jako zespół teoretycznych i metodologicznych założeń, ujmuje rzeczywistość społeczną jako zespół wielowymiarowych relacji. W tym sensie każdy badany obiekt traktować należy strukturalnie, gdyż tylko w przestrzeni relacji możliwe jest rozpoznanie jego charakterystyk, cech, specyficznych społecznych znaczeń itd. Zaprzeczeniem relacjonalizmu jest substancjalizm. Przykładowo relacyjne rozpoznanie „klasy średniej” jest możliwe tylko przy zarysowaniu klasy wyższej i niższej, gdyż to właśnie „średniość” jej pozycji, usytuowanie między dwiema skrajnymi klasami wpływa na to, co nazywamy „kondycja klasy średniej” - zob. Bourdieu, Wacquant (2001). 
przez nas perspektywie socjologicznej - kapitałami ${ }^{13}$, którym przyznaje się większy lub mniejszy społeczny prestiż (uznanie, które jest faktyczną społeczną legitymizacja).

Tym samym ukazujemy Trybunał jako miejsce rywalizacji różnorodnych sił (politycznych, akademickich itp.), które znajdują odzwierciedlenie w jego składzie osobowym w konkretnym czasie i wpływają na zmianę sposobu legitymizacji. Naszym zamierzeniem jest więc dokonanie - metodą prozopograficzną (czyli analizą biografii zbiorowych) ${ }^{14}$ - systematycznej analizy kapitałów składu sędziowskiego i tym samym ujawnienie logiki legitymizacji polskiego sądu konstytucyjnego. Takie porównawcze ujęcie - zestawiające dużą liczbę charakterystycznych cech - może ujawnić zależności i różnice, które umykaja, gdy dokonuje się badania jednostek w wyizolowaniu.

Jak pokażemy, legitymizacja Trybunału jest skomplikowana, gdyż wielowymiarowa. Angażuje ona także inne pola społeczne, takie jak pole akademickie czy biurokratyczne (pole instytucji państwowych), które z racji swego społecznego usytuowania względem siebie, a zwłaszcza względem pola politycznego stanowią istotny, chociaż nie zawsze zauważalny aspekt legitymizacji TK. Oznacza to, że napięcie nie występuje wyłącznie na styku: prawo versus polityka, a wymiary zależności sa znacznie bardziej złożone.

Co więcej, legitymizacja Trybunału jest zmienna w czasie ${ }^{15}$, dlatego poza wymiarem synchronicznym (ukazującym komponent rywalizujących $\mathrm{w}$ danym momencie sił) rozpatrzymy ją diachronicznie - naukowo formalizując jej dynamikę.

Reasumujac, pierwszym krokiem naszych działań będzie nakreślenie przez analizę kapitałów sędziów - przestrzeni Trybunału. Następnie wyodrębnienie okresów (umownie zwanych tutaj „kadencjami”), w których powoływane były poszczególne składy, i umieszczenie ich we wcześniej skonstruowanej przestrzeni. W ten sposób uchwycimy, jak Trybunał wraz ze zmianą zasiadających w nim jednostek (a w zasadzie kapitałów, jakie jednostki te skumulowały) zmienia się w czasie. Odtworzenie trajektorii całego sądu konstytucyjnego (od 1985 do 2018) pozwoli zaś zaobserwować faktyczne zmiany w sposobie jego legitymizacji. Jako że wyboru sędziów dokonują partie polityczne, tę zmienną (partia polityczna delegująca danych sędziów do TK) także umieścimy w skonstruowanej wcześniej przestrzeni. Pokaże to, jak układ sił - kapitałów w określonych momentach zmieniał Trybunał i jakie zasoby legitymizacyjne dla poszczególnych partii były istotne przy wyborze kandydatów. Jest to szczególnie interesujące w świetle ostatnich nominacji (w latach 2015-2018), które

${ }^{13}$ Kapitał to znaczący zasób, który posiada dana jednostka. Zasób ten nie jest wyłącznie wymogiem formalnym, ale jest rozpoznawany przez inne jednostki jako istotny, ważny, prestiżowy, przez co może być brany pod uwagę jako znaczący w procesie wyboru na sędziego Trybunału (np. stopień naukowy mogący konotować wiedzę prawnicza, długoletnie wykonywanie zawodu sędziego, rozpoznawalność związana z pełnieniem funkcji państwowych itp.). Zob. Bourdieu (1986): 241-258. Dany sędzia TK jest zatem traktowany w badaniu nie jako konkretny człowiek, ale jednostka epistemiczna - nośnik zdobytych w trakcie swojego życia kapitałów, dzięki którym zajmuje kolejne pozycje w świecie społecznym (np. profesora prawa, członka komisji kodyfikacyjnej, sędziego TK). O tej metodologii zob. Bourdieu (1988a): 21; Dezaley, Garth (1996): $281 \mathrm{n}$.

${ }_{14}$ Zob. Charle et al. (1980).

15 Dębska, Warczok (2017): 63-74. 
budzą - jak się wydaje - silniejsze niż dotąd emocje. Całość analizy uzupełniona zostanie ilustracją zmieniającej się opinii publicznej na temat polskiego Trybunału Konstytucyjnego. Pozwoli to, przynajmniej w pewnym zakresie, unaocznić szerszy społeczny efekt procesu legitymizacji tej instytucji.

\section{METODA I DANE}

Jak zaznaczyliśmy, wgląd w głębsze zależności badanej przez nas przestrzeni jest możliwy wyłącznie przez wyjście (choć nie ich negację) poza ściśle prawnicze perspektywy, a więc zastosowanie metod empirycznych. Badanie prowadzimy zatem za pomoca geometrycznej analizy danych, a precyzyjniej: wielorakiej analizy korespondencji (WAK; ang. Multiple Correspondence Analysis - MCA) ${ }^{16}$, metody, która stanowi formalne ujęcie struktury przestrzeni społecznej i niejednokrotnie była stosowana w różnych tego typu badaniach ${ }^{17}$. Najbardziej znane to zarysowanie i wyjaśnienie praktyk kulturowych we Francji ${ }^{18}$ czy też przestrzeni świata akademickiego w tym kraju ${ }^{19}$. Ze względu na to, że metoda ta jest stosowana w Polsce w badaniach nad prawem po raz pierwszy, wymaga kilku bazowych wyjaśnień.

Wieloraka analiza korespondencji kondensuje informacje o cechach społeczno-demograficznych sędziów (ich kapitałach, które są poszczególnymi zmiennymi) i ujmuje je w formie wykresu (mapy). Mapa ta - zdefiniowana przez prostopadłe do siebie osie (wymiary) - ukazuje główne opozycje cech (zmiennych) na płaszczyźnie ${ }^{20} \mathrm{i}$ jest reprezentacją przestrzeni społecznej (w tym przypadku TK). Przedstawia się ją w formie dwuwymiarowej płaszczyzny lub płaszczyzn dwóch prostopadłych osi, np. oś 1 i 2 , na kolejnym wykresie 2 i 3 itd. To, ile wymiarów danej przestrzeni poddanych zostanie interpretacji, zależy od uzyskanych wyników. Zadaniem badacza jest określenie - po przeprowadzeniu wstępnej analizy, wyrysowaniu mapy oraz określeniu liczby intepretowanych wymiarów - znaczenia poszczególnych osi stanowiących główne struktury dzielące przestrzeń (jego ukryte reguły). Odbywa się to na podstawie szczegółowej inspekcji rozmieszczenia kategorii zmiennych, najpierw aktywnych (tych, które uczestnicza w konstrukcji osi), później pasywnych (nieuczestniczących w tej budowie) oraz ulokowania tam jednostek. Jednostki „podobne” do siebie (pod względem analizowanych cech społecznych, posiadających zbliżony zakres bądź strukturę kapitałów), leżą na wykresie w bliskiej odległości, z kolei jednostki różniące się od siebie pozostaja od siebie oddalone.

Przeprowadzone przez nas badanie oparte jest na szczegółowej analizie źródeł zastanych. Obejmuje ono wszystkich orzekajacych od roku 1985 do 2018

${ }^{16}$ Zob. Le Roux, Rounet (2010).

${ }^{17}$ Lebaron (2006): 1-37; (2008): 121-144.

${ }^{18}$ Bourdieu (2005).

${ }^{19}$ Bourdieu (1988).

${ }^{20}$ Każda z tych osi wyjaśnia odpowiedni zakres wariancji (odchylenia standardowego od średniej) w porządku malejącym: pierwsza wyjaśnia najwięcej, druga nieco mniej itd. 
$(\mathrm{N}=68)$ sędziów $\mathrm{TK}^{21}$. Głównymi źródłami danych są oficjalne strony i portale internetowe zawierające informacje biograficzne: urzędowa strona TK, strony uczelni wyższych, samorządów zawodowych, polskiego parlamentu itp.

Aby nakreślić przestrzeń Trybunału Konstytucyjnego i jego wewnętrzne zróżnicowania, tak by uchwycić logikę wyboru kandydatów w czasie, uwzględniliśmy 16 zmiennych aktywnych, posiadających łącznie 35 kategorii, które uporządkowaliśmy w trzech następujących blokach:

Blok 1: Akademicki kapitat prawniczy, w którym wyróżniliśmy następujące zmienne:

a) stopnie i tytuły naukowe (4 kategorie: mgr, dr, dr hab., profesor),

b) ukończona uczelnia wyższa (3 kategorie pogrupowane stopniem prestiżu: wysoki, średni, niski, zgodnie z Rankingiem Wydziałów Prawa przeprowadzanym przez „Perspektywy”22),

c) Międzynarodowe doświadczenie akademickie (studia za granica, wyjazdy i staże naukowe - kodowane: tak/nie).

Blok 2: Zawodowy kapitat prawniczy, w którym uwzględniliśmy następujące zawody (kodowane tak/nie):

a) sędzia,

b) prokurator,

c) adwokat,

d) radca prawny.

Blok 3: Dodatkowy kapitat prawniczy: zajmowanie pozycji w organach konstytucyjnych ${ }^{23}$ (kodowane tak/nie), tj.:

a) Sąd Najwyższy i/lub Naczelny Sąd Administracyjny,

b) Trybunał Stanu,

c) Trybunał Konstytucyjny (np. jako asystent sędziego) i Biuro Rzecznika Praw Obywatelskich (jako Ombudsman per se, czy też asystent/pracownik Biura RPO).

Blok 4: Kapitat pozaprawny - znacząca pozycja w innych przestrzeniach społecznych (kodowane tak/nie), tj.:

a) parlament (tzw. kapitał polityczny, pełnienie funkcji ściśle politycznych: poseł, senator),

b) administracja rządowa (tzw. kapitał państwowy, np. wiceminister gabinetu, podsekretarz stanu itp.),

${ }^{21}$ Jednostkami analizy byli sędziowie wykonujący funkcje orzecznicze. W tym sensie sędziowie prawomocnie wybrani, ale nie zaprzysiężeni nie spełniali przyjętego przez nas warunku. Oznacza to uwzględnienie tzw. dublerów (m.in. Lech Morawski, Henryk Cioch), a pominięcie np. Andrzeja Jakubeckiego, Krzysztofa Ślebzaka, Romana Hausera. Osoby te zostały uwzględnione w badaniach jako jednostki pasywne.

22 Perspektywy.pl (2018).

${ }^{23} \mathrm{~W}$ literaturze z zakresu prawa konstytucyjnego nie ma pełnej zgodności co do kwalifikowania poszczególnych organów w konkretne kategorie. Za uregulowaniami konstytucyjnymi i literatura przedmiotu (Krajewski 2007) przyjęliśmy, że organami wymiaru sprawiedliwości sa SN i NSA, które razem z TS tworzą organy sądowe. RPO zgodnie z rozdziałem IX potraktowano jako organy kontroli państwowej i ochrony prawa. Jesteśmy świadomi, że określenie zbiorcze tych podmiotów jako „organy konstytucyjne” jest częściowo arbitralne, jednakże uzasadnione potrzebami pracy. 
c) ekspert międzynarodowy (np. ONZ, Rady Europy),

d) ekspert parlamentu,

e) ekspert rząu,

f) ekspert legislacji (członek komisji kodyfikacyjnych, rad legislacyjnych itp.).

Poza powyżej wskazanymi zmiennymi aktywnymi, mającymi wpływ na konstrukcję badanej przez nas przestrzeni, skonstruowaliśmy dwie zmienne pasywne: „kadencja” i „partia polityczna”. Ustalenie pierwszej z nich nastręczało trudności ze względu na indywidualny charakter wyboru sędziów do TK, a także zmiany przepisów w długości sprawowania funkcji, z jakimi mieliśmy do czynienia w badanym czasie. Jednakże udało się wyodrębnić pewne okresy, które ujęliśmy następująco: kadencja 0 (K0) to sędziowie wybierani w reżimie państwowego socjalizmu od 1985 r. (13 sędziów) ${ }^{24}$; kadencja 1 (K1): sędziowie wybierani od 1989 (15 sędziów) ${ }^{25}$; kadencja 2 (K2): sędziowie wybierani od 1997 (15 sędziów); kadencja 3 (K3): sędziowie wybierani od 2006 (15 sędziów), kadencja 4 (K4): sędziowie wybierani od 2015 (13 sędziów) ${ }^{26}$. Jako drugą zmienna uzupełniająca uwzględniliśmy wszystkie partie polityczne, które wysuwały poszczególnych kandydatów na stanowiska między rokiem 1985 a 2018. Następnie przeprowadziliśmy wieloraką analizę korespondencji i ustaliliśmy dwa główne wymiary (osie) charakteryzujące przestrzeń Trybunału Konstytucyjnego ${ }^{27}$.

\section{PODSTAWOWE PODZIALY W PRZESTRZENI TRYBUNAŁU KONSTYTUCYJNEGO}

Pierwsza, pozioma oś ukazuje najważniejszy podział występujący w badanej przez nas przestrzeni ${ }^{28}$. Na wykresie 1 przedstawiliśmy wyłącznie te aktywne kategorie zmiennych, które mają największy wkład w konstrukcję pierwszego wymiaru (zob. wartości tabeli 1$)^{29}$.

${ }^{24}$ W pierwszym składzie wybrano 12 sędziów, Henryk De Fiumel zmarł w pierwszym roku orzekania i na jego miejsce wybrano Marię Łabor-Sorokę.

${ }^{25}$ Wybrana tu liczba sędziów jest wyższa od 12 ze względu na śmierć Janiny Zakrzewskiej i zrzeczenie się funkcji przez dwóch sędziów: Błażeja Wierzbowskiego i Wojciecha Sokolewicza. Wszyscy ci sędziowie zostali wybrani przed zmianą przepisów dotyczących TK i wejściem w życie Konstytucji z 1997, dlatego właśnie ten rok wyznaczył kolejną cezurę między naszymi umownymi kadencjami.

${ }^{26}$ Skład sędziowski w dniu zakończenia badań (1 kwietnia 2019 r.) tworzy kilku sędziów kadencji trzeciej i większość z kadencji czwartej. Po 1 kwietnia 2019 r. wybranych zostało czterech sędziów do TK. Tym samym można mówić o rozpoczęciu się nowej, piątej kadencji w historii TK.

${ }^{27}$ Analiza została przeprowadzona za pomoca programu SPAD 9.1. Każda z tych osi wyjaśnia odpowiedni zakres wariancji w porządku malejącym (pierwsza najwięcej, druga nieco mniej itd.). Na podstawie zmodyfikowanego wskaźnika Benzécriego ustaliliśmy, że oś pierwsza wyjaśnia 42,7\% wariancji, druga 23,3\%, kolejne: trzecia 13,6\%, czwarta zaś 12,9\%. Wskaźnik ten pozwala na określenie liczby osi, którą mają być wykorzystane w analizie, dlatego biorcą pod uwage przedstawione wyniki, zachowaliśmy wyłącznie dwie pierwsze osie. Zob. Benzécri (1992): 405.

${ }^{28}$ Zob. przypis wyżej.

${ }^{29}$ Określa się ją na podstawie średniej wkładu poszczególnej kategorii do wariancji całościowej osi (tutaj: 2,86\%). Oznacza to, że zaproponowane na rysunku kategorie przekroczyły ten poziom, ergo kategorie, które tej granicy nie przekroczyły, nie zostały przedstawione na rysunku. 


\section{Wykres 1}

Płaszczyzna osi 1-2 z kategoriami, których udział w konstrukcji osi 1 jest większy od średniej

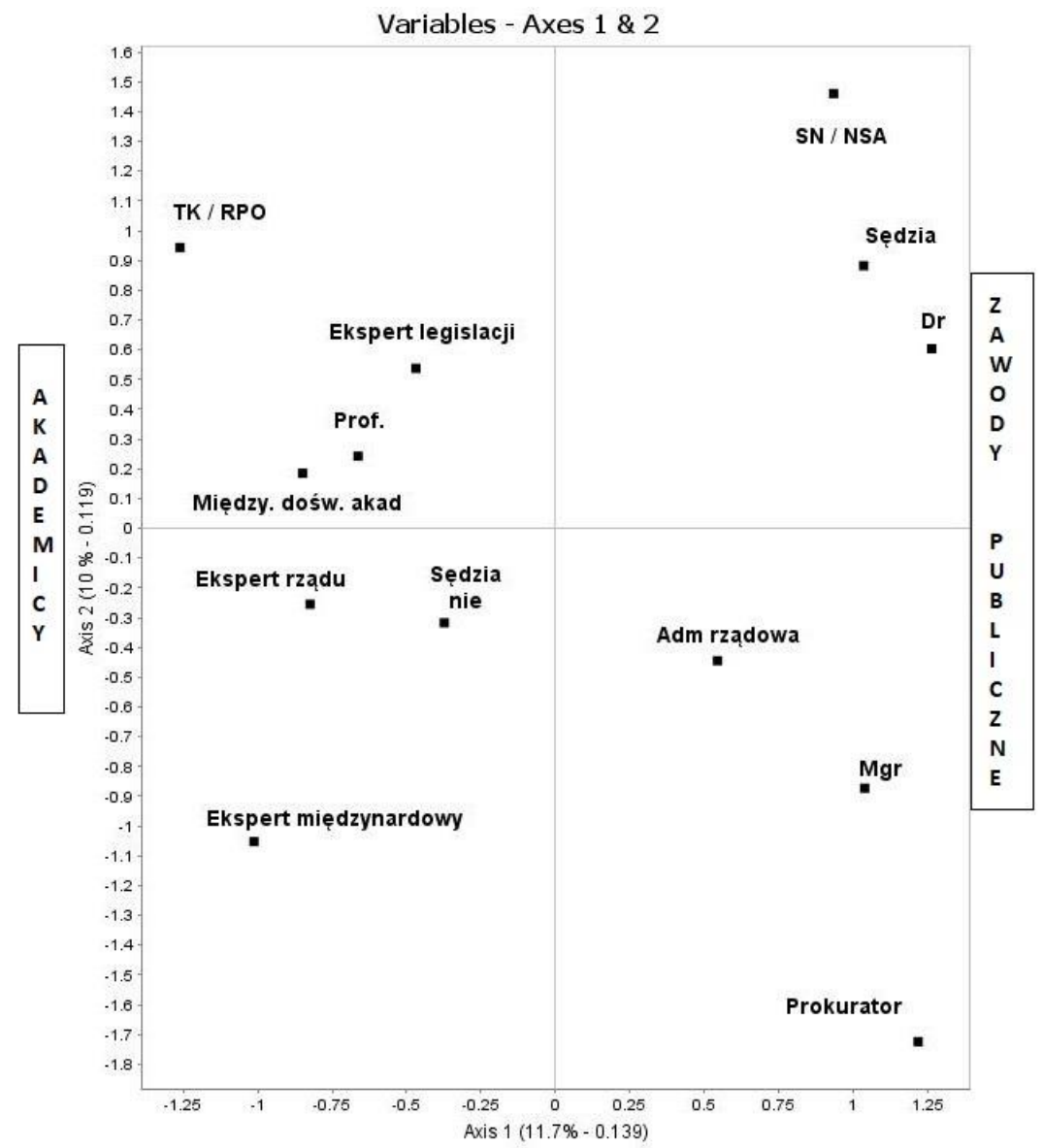

Źródło: opracowanie własne.

Wizualna inspekcja wykresu pozwala dostrzec, że po prawej stronie wykresu (osi) znajdziemy najczęściej jednostki wykonujące zawody prawnicze, które określić można jako publiczne, czyli sędziów i prokuratorów. Jednocześnie nie pojawiają się tam ani adwokaci, ani radcowie prawni. W przeważającej większości jednostki znajdujące się na tym biegunie osi charakteryzuje brak tytułu naukowego i choć niektórzy posiadaja stopnień doktora, to w ich przypadku nie oznacza on kontynuacji kariery naukowej. Ponadto znajdujący się po tej stronie wykresu sędziowie nierzadko orzekali w SN lub NSA. Dodatkowym, uzupełniającym kapitałem dla osób ulokowanych na omawianym biegunie diagramu było zajmowanie pozycji w rządzie, w szczególności podsekretarza stanu w ministerstwie. Ten biurokratyczny, państwowy kapitał odgrywał tu jednak niewielką rolę, o czym świadczy analiza wkładu tej kategorii do całości 
osi - przekracza ona ustaloną dla osi średnia, ale najmniej wśród wszystkich kategorii po tej stronie osi (por. wartości Aneks, tabela 1).

Po lewej stronie wykresu znajdują się osoby wyposażone w znaczace zasoby o charakterze akademickim. Ci sędziowie Trybunału to najczęściej profesorowie prawa, posiadający nierzadko akademickie doświadczenie za granicą. Zdecydowana większość z nich wywodzi się ze środowiska naukowego, dlatego wcześniej nie podejmowali czynności stricte orzeczniczych w sądownictwie powszechnym. Jednakże niektórzy z nich przed mianowaniem na sędziów sądu konstytucyjnego pracowali w nim jako asystenci. Oznacza to, że część ulokowanych po lewej stronie akademików w momencie powołania działała już stosunkowo długo w strukturach TK. Jeszcze inni zdobywali doświadczenie zawodowe w Biurze Rzecznika Praw Obywatelskich. Co więcej, niektórzy z nich dużą część swojej kariery zawodowej spędzili, łącząc działalność naukową z praca ekspercką w rządzie, parlamencie, a także - do pewnego stopnia z praca legislacyjną w komisjach kodyfikacyjnych i radach legislacyjnych.

Podsumowując, analiza pierwszej osi pozwala z łatwością dostrzec, że podstawowy podział przestrzeni TK przebiega zgodnie z klasycznym dla całej przestrzeni prawnej, podziałem na biegun zawodów prawniczych (z tym zastrzeżeniem, że są tu ulokowani wyłącznie sędziowie i prokuratorzy) i biegun akademicki (profesorowie prawa) ${ }^{30}$. Ujawnia ona także pewną głębszą strukturę - różnice w dodatkowych zasobach. Publiczni prawnicy zawodowi nie tylko czerpią z innych niż akademicy dodatkowych zasobów (kapitał państwowy, a nie ekspercki), ale przede wszystkim czynią to w mniejszym zakresie. Najwyraźniej tym zawodowym prawnikom żaden dodatkowy zasób nie jest niezbędny w grze o stanowisko w TK.

Przejdźmy zatem do drugiego wymiaru. Tak jak wcześniej na wykresie 1 również tutaj przedstawiliśmy wyłącznie te aktywne kategorie zmiennych, które mają największy wkład w konstrukcję drugiego wymiaru (zob. wartości tabela 2).

Oś pionowa wyraźnie dzieli przestrzeń TK na zawodowych sędziów i jednostki wykonujace przed wyborem na stanowisko w TK inne zawody prawnicze, w szczególności prokuratora. W górnej części osi zlokalizowani sa w szczególności ci sędziowie zawodowi, którzy w swojej karierze przeszli przez wszystkie szczeble sądownictwa powszechnego aż do stanowiska sędziego SN lub NSA. Można więc konkludować, że w przypadku tych kandydatów droga do Trybunału była przede wszystkim wynikiem awansu w strukturze systemu sądownictwa. To biegłość orzecznicza - prawniczy zasób zawodowy - był kluczowym kapitałem, które posiadali.

Ponadto tego rodzaju profil jest typowy dla osób, które przed nominacja pracowały w TK i/lub w biurze RPO. Co więcej, nierzadko były ekspertami w procesie stanowienia prawa. Ten szczególny rodzaj kapitału eksperckiego ma mniejsze znaczeni niż na osi pierwszej (por. wartości tej kategorii Aneks, tabela 1 i 2).

30 Zob. Dębska (2016): 41. Co nie oznacza, że wśród sędziów Trybunału nie znajdziemy jednostek posiadajacych zarówno kapitał naukowy, jak i zawodowy. 


\section{Wykres 2}

Płaszczyzna osi 1-2 z kategoriami, których udział w konstrukcji osi 2 jest większy od średniej

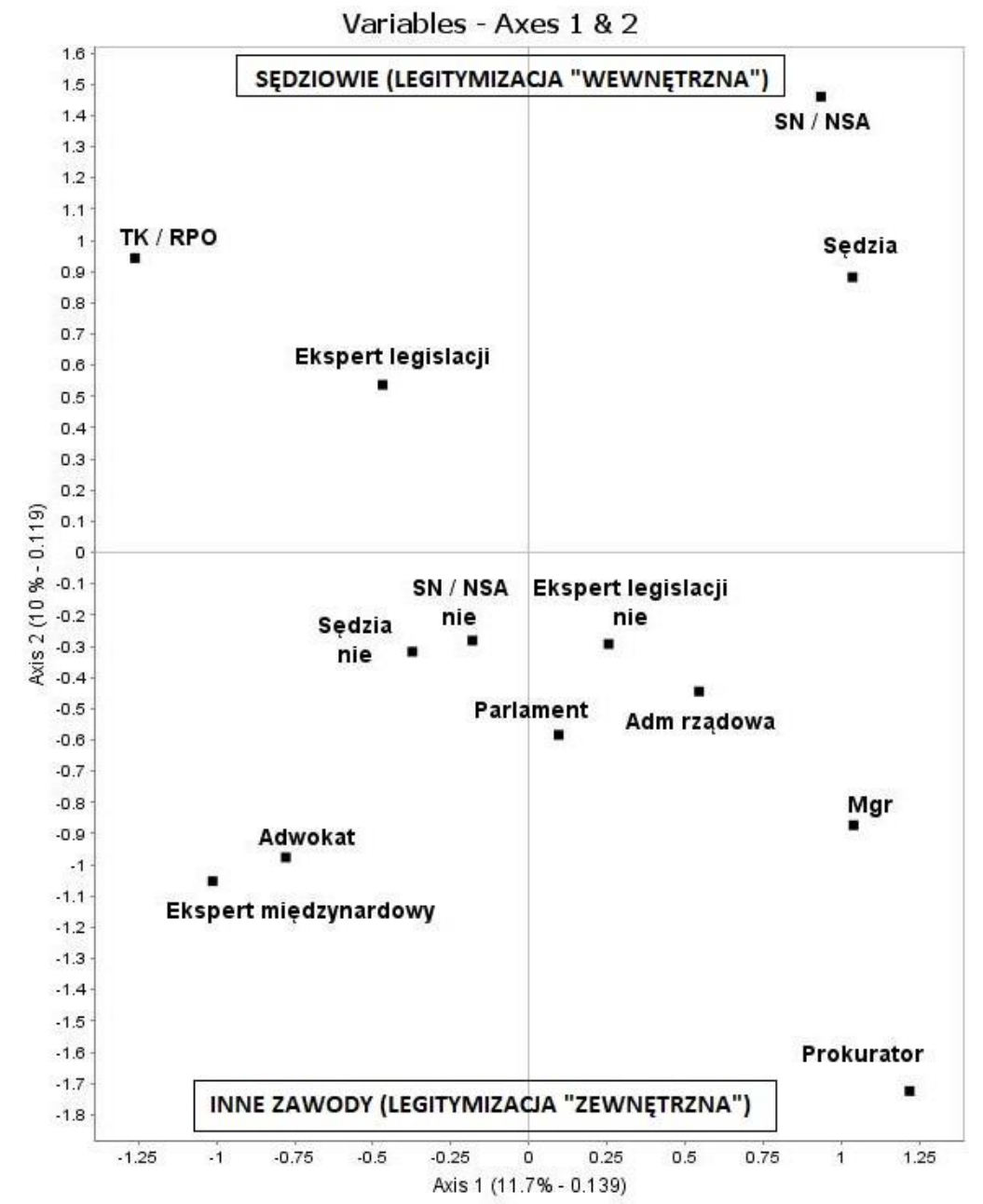

Źródło: opracowanie własne.

Dolną część diagramu charakteryzuje obecność prokuratorów i adwokatów, którzy nierzadko sprawowali funkcje poselskie i/ lub senatorskie w parlamencie. Łączy ich brak naukowych stopni i tytułów. Prócz tego nie pracowali nigdy w systemie sądownictwa żadnego szczebla. Niemniej jednak niektórzy z nich byli ekspertami międzynarodowych instytucji czy też pracowali w administracji rządowej. Widać więc bardzo wyraźnie, że ich dodatkowe zasoby pochodzą z przestrzeni pozaprawnej, zwłaszcza zaś politycznej.

Podsumowując, analiza drugiej osi ujawnia różnicę w trajektoriach między zawodami prawniczymi w przestrzeni TK. Część jednostek była nominowana w momencie orzekania w SN lub NSA. Droga kariery tych sędziów 
nie zależała tak bardzo - jak w przypadku prokuratorów i adwokatów - od kapitału pozaprawnego. Można więc twierdzić, że oś pionowa wyraźnie przeciwstawia „wewnętrzną" trajektorię kandydatów, czyli ścieżkę do TK przez system sądowniczy - ścieżce „zewnętrznej”, dzięki której do sądu konstytucyjnego wchodzą adwokaci i prokuratorzy - wzbogaceni dodatkowo o kapitał polityczny (parlament), a także - jak przede wszystkim w przypadku adwokatów - o międzynarodową działalność.

\section{TRAJEKTORIA TRYBUNAŁU (1985-2018)}

Wieloraka analiza korespondencji umożliwia wgląd w głębsze zależności badanej przestrzeni, dzięki wykorzystaniu zmiennych pasywnych (uzupełniających). W niniejszym przypadku - jak była o tym mowa - potraktujemy tak zmienne: „kadencja” i „partia polityczna” (zgodnie ze wcześniejszym zdefiniowaniem), a następnie umieścimy je na skonstruowanej wcześniej mapie (z najważniejszymi wskazanymi podziałami), aby ukazać zmianę legitymizacji sądu konstytucyjnego w czasie.

Jak można zauważyć, trajektoria Trybunału - oznaczona przez widoczne na wykresie „punkty środkowe” ${ }^{31}$ poszczególnych kadencji - wyraźnie pokazuje przesuwanie się sądu konstytucyjnego od kadencji 0 aż do kadencji 3 na osi poziomej, czyli od bieguna zawodowego (sędziowsko-prokuratorskiego) w kierunku bieguna akademickiego (profesorów prawa). Biorąc pod uwagę opisane wcześniej charakterystyki, można mówić o przesuwaniu się od zasobów ściśle prawniczych i biurokratycznych (państwowych) do akademickich.

Jednakże szczegółowa analiza ujawnia głębszą zmianę, jaka nastapiła w kadencji 3. Kadencje 0, 1 i 2 nie różnią się od siebie znacząco, co możemy stwierdzić przez porównanie odległości między współrzędnymi punktów środkowych poszczególnych kadencji 1, 2, 3 a barycentrum - punktem przecięcia osi 1 z 2 na obu osiach (dla kadencji 0 na osi pierwszej wartość ta wynosi 0,297, na osi drugiej - 0,21; dla kadencji 1 na osi pierwszej - 0,191, drugiej - 0,037; dla kadencji 2 na osi pierwszej - 0,096, na drugiej - 0,036). Zatem trajektoria Trybunału przebiega od bieguna zawodowego w kierunku akademickiego. Zbliżanie się poszczególnych kadencji ku środkowi osi (barycentrum) oznacza również, że wzorce kariery poszczególnych sędziów (wyznaczone przez skumulowane przez nich kapitały) pierwszych trzech kadencji $(0,1,2)$ były dość różnorodne. Innymi słowy, można powiedzieć, że sędziowie ci - przez swoją niejednorodność - wnosili odmienne zasoby legitymizacyjne do całości społecznej konstrukcji Trybunału.

31 „Punkt środkowy” danej kadencji ulokowany jest na płaszczyźnie dokładnie pośrodku położenia tych wszystkich jednostek, które wybrane zostały w danej kadencji. Można więc powiedzieć, że jest to lokalny punkt grawitacji, skupiający jednostki przynależące do określonej kategorii (np. jak w tym przypadku, fakt wyboru w danej kadencji). Współrzędne tego punktu odczytuje się na obu osiach, przy czym wartość negatywna bądź pozytywna jest czysto arbitralna i nie niesie żadnych dodatkowych znaczeń. Zob. Le Roux, Rounet (2010): 67. 
Wykres 3

Kadencje i partie polityczne przedstawione na płaszczyźnie osi 1 i 2

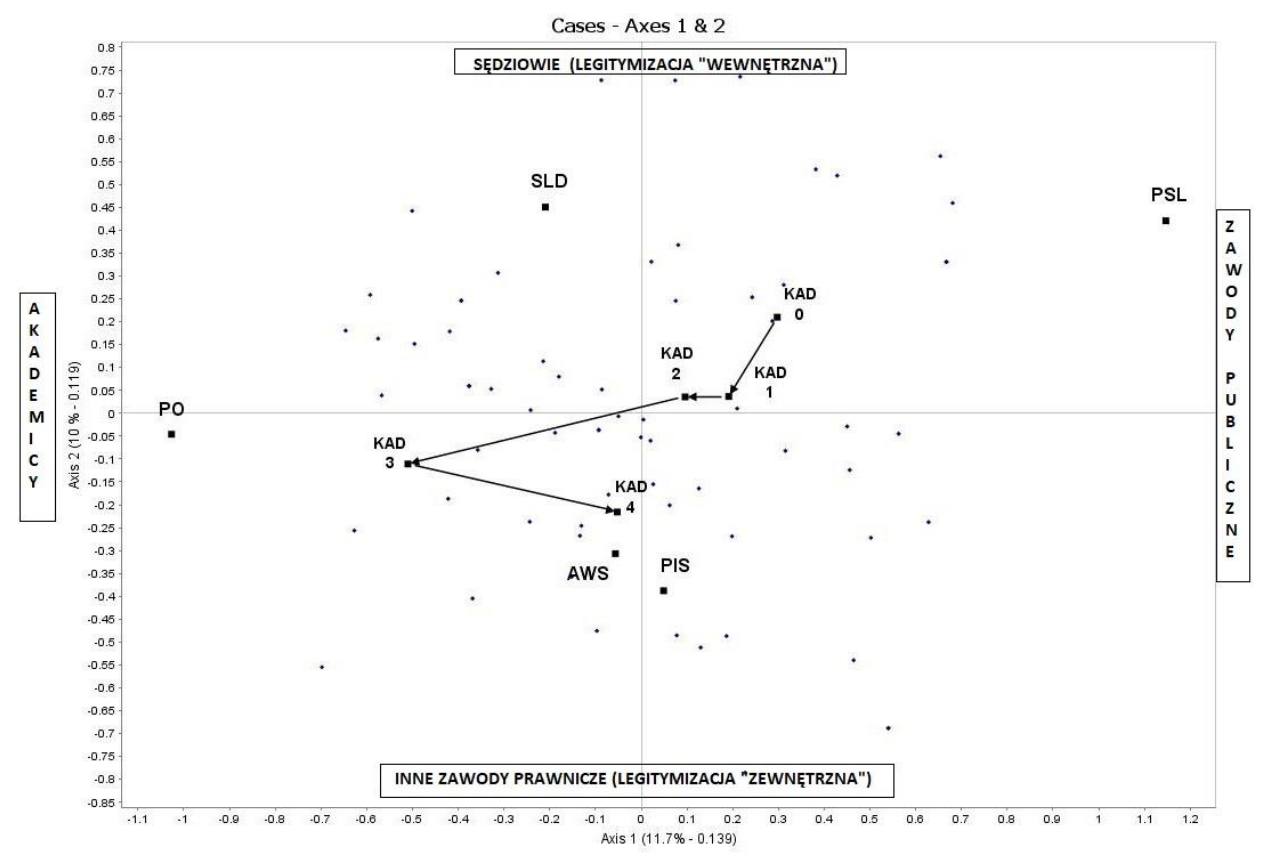

Wykres 3 przedstawia wybrane partie polityczne zaprezentowane na płaszczyźnie jednostek. Nieopisane punkty rozrzucone w przestrzeni grafu są punktami położenia poszczególnych sędziów.

Źródło: opracowanie własne.

Jak zatem widzimy, początkowa legitymizacja TK opierała się na dość równej kompozycji znaczących w przestrzeni Trybunału kapitałów, z pewna przewaga profesjonalnego zasobu sędziowskiego (szczególnie w kadencji 0). Stopniowe coraz wyraźniejsze uzupełnienie go o przeciwstawny kapitał akademicki zapewniało istotny dla całościowej legitymizacji pluralizm, który jest wyjątkowo wydajny legitymizacyjnie. Zapewnienie różnorodności kapitałów jest pewnego rodzaju gwarancją zróżnicowania typów władzy, ergo osłabiania jej arbitralności, co tym samym wspiera legitymizację całego sądu konstytucyjnego. Kadencja 2 przez największą heterogeniczność znajduje się najbliżej punktu środkowego przecinającego oś pierwszą z druga, jest więc najbardziej wyważona, co zapewnia Trybunałowi legitymizację, którą można określić jako legitymizację ze zróżnicowanych zasobów (w którym sąd konstytucyjny pozostaje pod wpływem różnych, rywalizujących między sobą sił, ale pozostaje niezdominowany przez jedną grupę) $)^{32}$.

Kadencja trzecia wyraźnie się zatem wyróżnia, stanowiąc uwieńczenie konsekwentnego przesuwania się Trybunału ku biegunowi akademickiemu.

${ }^{32}$ Zob. Lebaron (2012): 226. 
O ile dotąd Trybunał zmierza ku akademikom stopniowo, o tyle w kadencji 3 wyraźnie przesuwa się ku temu biegunowi przestrzeni (położenie punktu środkowego kadencji 3 osiaga wartość -0,51; jak dotąd jest to punkt najdalej wysunięty na pierwszej osi). Nie budzi wątpliwości, że w historii polskiego sąu konstytucyjnego ta kadencja jest $\mathrm{w}$ najwyższym stopniu zakademizowana. Sędziowie wówczas wybrani to głównie profesorowie zwyczajni (lewa strona osi 1), którzy wnoszą naukową legitymizację do TK. I ten rodzaj legitymizacji jest niezwykle efektywny, gdyż akademia i nauka postrzegane sa jako neutralne i bezstronne, oddalone od przyziemnych interesów ekonomicznych i politycznych, co sprzyja społecznemu budowaniu autonomii Trybunału (rozumianej jako niezależność wobec bezpośrednich sił politycznych).

Kadencja ostatnia - 4 - zmienia trajektorię Trybunału dotąd zmierzającego ku akademizacji. Tym razem przemieszczenie następuje w odmiennym niż dotąd kierunku, ku biegunowi zawodowemu (prokuratorsko-adwokackiemu) wzbogaconemu (znacznie wyraźniejszym niż dotąd) kapitałem politycznym.

Niewattpliwie jest to zmiana istotna. $Z$ jednej strony następuje znaczące przeciwstawienie biegunowi sędziowskiemu (kadencja 4 jest najdalej wysuniętą na negatywnej stronie drugiej osi w historii TK -0,388; por. w szczególności punkty środkowe kadencji 0 i 4 na drugiej osi), z drugiej stosunkowo silne przeciwstawienie się legitymizacji akademickiej (dość znaczne przesunięcie kadencji 4 względem kadencji 3 na pierwszej osi) z jednoczesnym oddaleniem od bieguna zawodowego (por. w szczególności analizując punkty środkowe kadencji 0 i 4 na pierwszej osi). Bezsprzecznie można zatem mówić o zauważalnej zmianie społecznej legitymizacji polskiego sądu konstytucyjnego.

\section{LOGIKA WYBORÓW PARTYJNYCH}

Jak pokazaliśmy, proces legitymizacji Trybunału przebiega w wielopłaszczyznowej przestrzeni społecznej, która jest dynamiczna. Trybunał orbituje zatem jak planeta - przyciagany i odpychany siłą oddziałujących na niego światów (raz akademii, raz zawodów prawniczych, innym razem polityki itd.), zbliża się bądź oddala od nich, przyjmując bądź odrzucając charakterystyczne dla nich cechy. Każdy świat społeczny dysponuje bowiem istotnymi zasobami (akademia - tytułami naukowymi; polityka - stanowiskami politycznymi itp.), które znajdują odzwierciedlenie w przestrzeni Trybunału, w jego składzie osobowym w konkretnym czasie. W zależności od konfiguracji tych kapitałów legitymizacja Trybunału zmienia się - co pokazaliśmy szczególnie wyraźnie porównując kadencje. Warto zatem rozważyć, jaki charakter ma ostatnio przyjęta logika legitymizacyjna TK.

Ostatnia kadencja (która rozpoczęła się w 2015 r.) jest szczególna, gdyż - jak wzmiankowaliśmy - część sędziów wybrano w sposób naruszający dotychczasowe zasady ${ }^{33}$. Wydarzenia, które rozgrywały się wokół Try-

${ }^{33}$ Łętowska, Wiewiórowska-Domagalska (2016). 
bunału wyraźnie korespondowały ze zmianami wprowadzanymi w całym sądownictwie ${ }^{34}$ i były konsekwencją polityki „wymiany”35 i „przebudowy polskich elit" ${ }^{36}$.

Logikę tej zmiany można głębiej wyjaśnić, analizując wybory sędziów przez poszczególne partie (przy zastrzeżeniu, że nie pokrywają się ściśle z kadencjami). Ze względu na znaczne rozproszenie i nieustanne zmiany polskiego systemu partyjnego wybraliśmy tylko te, które desygnowały więcej niż pięciu sędziów w całej historii Trybunału. Jak pokazuje wykres 3, partie polityczne w Polsce odznaczają się różnymi strategiami, np. PSL wybiera przede wszystkim prawników zawodowych (sędziów i prokuratorów nieakademików; na osi pierwszej punkt środkowy tej partii wynosi 1,147), SLD zaś najczęściej sędziów (na osi pierwszej -0,209), przeważnie będących jednocześnie akademikami (na osi drugiej 0,450).

Ze względu na to, że interesuja nas przede wszystkim ostatnie zmiany, przyjrzyjmy się bliżej dwóm partiom: Platformie Obywatelskiej (PO) i Prawu i Sprawiedliwość (PiS), które wyznaczają obecnie podstawowa oś sporu w politycznej przestrzeni. PO wybiera w głównej mierze akademików, nade wszystko profesorów (na osi pierwszej punkt środkowy tej kategorii osiaga wartość -1,027). Partia ta hołduje więc zdecydowanie legitymizacji naukowej Trybunału, w ten sposób budując jego autonomię względem polityki.

Po odmienne zasoby sięga PiS (wliczamy tu sędziów wybranych przez tę partię w całej historii Trybunału). Są to jednostki posiadajace kapitał zawodowy (przede wszystkim adwokacki i prokuratorski), uzupełniony w pewnej mierze o kapitał polityczny. O ile więc sędziowie desygnowali przez SLD odznaczali się legitymizacja „wewnętrzną" (sędziowska, budującą autonomię Trybunału jako organu władzy sądowniczej), o tyle ci wybierani przez PiS niemal wszyscy wywodzą się z zawodu innego niż sędzia (ta legitymizacja ,zewnętrzna", wzmocniona przez związki z polityką może być rozumiana jako rozbicie sędziowskiego esprit de corps). Ponadto analiza dodatkowych zmiennych (wiek sędziów, miejsce urodzenia, ukończony uniwersytet, tytuł naukowy i płeć) ukazuje, że PiS chętniej wybiera młodszych mężczyzn (poniżej średniej wynoszącej 53 lata dla całej populacji), pochodzaccych z mniejszych miejscowości (niż na przykład PO czy SLD), którzy w większości nie ukończyli uczelni najbardziej prestiżowych (proporcje sa odwrotnie w przypadku PO i jeszcze wyraźniejsze w przypadku SLD) i w zdecydowanej większości nie posiadaja tytułu profesora zwyczajnego (często sa zaś doktorami habilitowanymi), co współgra z polityka „wymiany elit”, chęci podważenia establishmentu. Ponadto wprowadzenie osób z większym niż dotąd kapitałem politycznym, a nade wszystko niesędziów (szczególnie nie z SN ani NSA) przyczynia się do osłabienia autonomii TK.

Należy jednak zwrócić uwagę na istotny fakt. Położenie kategorii PiS wynosi -0,388 na drugiej osi, przez co osiąga bezprecedensową jak dotąd na niej

\footnotetext{
${ }^{34}$ Luc (2018); Siedlecka (2018b), (2018a).

35 Wojciechowska (2014); Janicki, Władyka (2016).

36 Kaczyński (2014).
} 
odległość. Opisywana zmiana jest więc niezaprzeczenie zauważalna, jednakże charakterystyki wybieranych sędziów nie różnią się radykalnie od tych, którzy desygnowani byli przez pozostałe partie. Jest to bardzo ważne zastrzeżenie.

Każda władza dla swego trwania wymaga bowiem społecznej legitymizacji, która w przypadku władzy politycznej w nowoczesnych, demokratycznych społeczeństwach opiera się na wsparciu niezależnych instytucji prawnych. Im bardziej bezstronne w przekonaniu społecznym jest prawo, tym skuteczniej może uprawomocniać decyzje polityczne, które na prawie się opieraja. À rebours, żadna władza, nawet dysponująca najdoskonalszą propaganda, nie może sama się legitymizować. Musi zachować - choćby fasadowa, ale zewnętrzną wobec siebie samej - instytucję, która tę legitymizację będzie zapewniać. Innymi słowy, najbardziej efektywna legitymizacja następuje wtedy, gdy podmiot legitymizujacy pozostaje relatywnie niezależny od podmiotu, który legitymizuje (sędziowie Trybunału sa „oddzieleni” od polityków, których decyzje uprawomocniaja) ${ }^{37}$. PiS najwyraźniej dobrze zrozumiał tę zasadę, wyrażoną przez Pierre'a Bourdieu w Medytacjach pascaliańskich: „,...] siła pragnie być uzasadniona (a więc uznana, szanowana, honorowana, poważana), ale może być uzasadniona, kiedy zrezygnuje ze swego użycia [...]. Natomiast efekt uprawomocnienia jest największy, kiedy znika każda rzeczywista i widoczna relacja, mająca charakter korzyści materialnej lub symbolicznej, a ten, który dokonuje aktu uznania, sam cieszy się większym uznaniem"38.

Warto na koniec zaznaczyć, że całościowe i zmieniające się w czasie strategie legitymizacji polskiego Trybunału Konstytucyjnego znajduja „obiektywne" odzwierciedlenie w badaniach opinii publicznej, a precyzyjniej: stosunku Polaków do tejże instytucji. W pierwszej dekadzie XXI w., gdy instytucja ta ugruntowała się już w świadomości społecznej (o czym świadczy zwiększający się odsetek osób rozumiejących zasady działania TK), sąd konstytucyjny cieszył się dość wysokim zaufaniem społecznym (powyżej 50\%), a zdecydowana większość (ponad 80\%) wyrażała przekonanie o politycznej bezstronności tej instytucji i właściwym wypełnianiu przez nią obowiązku strażnika konstytu$\mathrm{cji}^{39}$. Jak wskazuje nasza analiza, zbiegło się to $\mathrm{w}$ czasie $\mathrm{z}$ uformowaniem się specyficznej i - jak widać wysoce wydajnej symbolicznie - legitymizacji akademickiej (naukowej) TK. Potwierdzeniem tego jest między innymi studium Grażyny Skapskiej i Grzegorza Brydy ${ }^{40}$, według którego Polacy sytuują na swych „mapach mentalnych” instytucje sądowe wysokiego szczebla, takie jak Sąd Najwyższy i Trybunał Konstytucyjny, w pobliżu szkolnictwa wyższego i co kluczowe - na przeciwległym biegunie do sfery politycznej (Sejmu, rządu itd.). Innymi słowy, TK w tamtym okresie kojarzył się w świadomości społecznej z obiektywizmem i bezstronnością nauki. Sytuacja ta zmieniła się wyraźnie po roku 2015. Już w 2016 zaufanie do TK spadło do 44\%, by w 2020 r. osiagnąć

\footnotetext{
37 Dębska, Warczok (2018): 72.

38 Bourdieu (2006): 149.

39 CBOS (2007).

40 Skapska, Bryda (2013).
} 
rekordowo niski poziom - 32\% $\%^{41}$. Spadek ten związany był oczywiście z politycznym kryzysem wokół Trybunału. Można jednak sądzić, że wpływ na to miała również zmiana formy legitymizacji tej instytucji - przejście od legitymizacji akademickiej ku bardziej politycznej. Jednocześnie, jak wskazaliśmy, nie można mówić o pełnej delegitymizacji TK, wszak co trzeci badany wciąż darzy tę instytucję zaufaniem.

Hanna Dębska

Uniwersytet Pedagogiczny w Krakowie

hanna.debska@up.krakow.pl

https://orcid.org/0000-0002-2541-1338

Tomasz Warczok

Uniwersytet Pedagogiczny w Krakowie

tomasz.warczok@up.krakow.pl

https://orcid.org/0000-0002-4488-3031

\section{ANEKS}

Tabela 1

Aktywne kategorie zmiennych na osi 1 ('średnia $-100 / 35=2,86$ )

\begin{tabular}{|l|c|c|}
\hline \multicolumn{1}{|c|}{ Nazwa zmiennej } & Kategoria & Wkład \\
\hline TK / RPO & Tak & 6,3 \\
\hline Ekspert międzynarodowy & Tak & 4,1 \\
\hline Ekspert rządu & Tak & 4,5 \\
\hline Międzynarodowe doświadczenie akademickie & Tak & 7,6 \\
\hline Tytuł & Prof & 8,7 \\
\hline Ekspert legislacji & Tak & 3,5 \\
\hline Sędzia & Nie & 4,6 \\
\hline Barycentrum & \multicolumn{2}{|c|}{} \\
\hline Administracja rządowa & Tak & 3,7 \\
\hline SN / NSA & Tak & 6,4 \\
\hline Tytuł & Mgr & 10,7 \\
\hline Sędzia & Tak & 12,8 \\
\hline Prokurator & Tak & 4,9 \\
\hline Tytuł & Dr & 5,3 \\
\hline
\end{tabular}

${ }^{41}$ Sondaż (2020). Zaufanie społeczne nie jest rzecz jasna obiektywnym wskaźnikiem legitymizacji. Pokazuje ono jednak w przybliżeniu, w jaki sposób zmiana form legitymizacji odzwierciedla się w świadomości społecznej. 
Tabela 2

Aktywne kategorie zmiennych na osi 2 ('średnia $-100 / 35=2,86$ )

\begin{tabular}{|l|c|c|}
\hline \multicolumn{1}{|c|}{ Nazwa zmiennej } & Kategoria & Wkład \\
\hline Prokurator & Tak & 11,5 \\
\hline Ekspert międzynarodowy & Tak & 5,1 \\
\hline Adwokat & Tak & 4,4 \\
\hline Tytuł & Mgr & 8,8 \\
\hline Parlament & Tak & 4,5 \\
\hline Administracja rządowa & Tak & 2,9 \\
\hline Ekspert legislacji & Nie & 2,9 \\
\hline Sędzia & Nie & 3,9 \\
\hline SN / NSA & Nie & 3,5 \\
\hline Barycentrum & \multicolumn{2}{|c|}{} \\
\hline Ekspert legislacji & Tak & 5,4 \\
\hline Sędzia & Tak & 10,8 \\
\hline TK / RPO & Tak & 4,1 \\
\hline SN / NSA & Tak & 18,1 \\
\hline
\end{tabular}

Benzécri, J-P. (1992). Correspondence analysis handbook. New York: Dekker.

Bojarski, Ł. (red.) (2007). Obywatelski monitoring kandydatów na sędziów. Raport. Warszawa.

Bojarski, Ł. (2010). Wybory sędziów do Trybunału Konstytucyjnego. Warszawa.

Bojarski, Ł. (2018). Pod społeczną kontrolą. Dziesięć lat Obywatelskiego Monitoringu Kandydatów na sędziów Trybunału Konstytucyjnego. Państwo i Prawo 73(5): 75-91.

Bourdieu, P. (1986). The forms of capital, [w:] J. Richardson (ed.), Handbook of Theory for the Sociology of Education. Westpoint, Greeenwood: 241-258.

Bourdieu, P. (1988a). Homo Academicus. Tłum. P. Collier. Stanford.

Bourdieu, P. (1988b). Program for sociology of sport. Sociology of Sport Journal 5(2): 151-161.

Bourdieu, P. (2005). Dystynkcja. Społeczna krytyka władzy sądzenia. Tłum. P. Biłos. Warszawa.

Bourdieu, P. (2006). Medytacje pascaliańskie. Tłum. K. Wakar. Warszawa.

Bourdieu, P. (2015). Sociologie Générale. Cours au Collège de France 1981-1983. Vol. 1. Paris.

Bourdieu, P., Wacquant L. J-D. (2001). Wprowadzenie do socjologii refleksyjnej. Tłum. A. Sawisz. Warszawa.

CBOS (2007) Opinie Polaków o Trybunale Konstytucyjnym. Komunikat z badań. Warszawa. <https://www.cbos.pl/SPISKOM.POL/2007/K_076_07.PDF>.

Charle, Ch., Nagle, J., Perrichet, M., Richard, M., Woronoff, D. (1980). Prosopographie des élites françaises: (XVIe-XXe siècles): guide de recherché. Paris.

Czeszejko-Sochacki, Z. (2003). Sądownictwo powszechne na tle porównawczym. Warszawa.

Dębska, H. (2015). Trybunał Konstytucyjny w poszukiwaniu legitymizacji. Szkic z socjologii prawa. Studia Prawnicze PAN 4(204): 23-41.

Dębska, H. (2016). Prawo jako pole. Ujęcie modelowe. Państwo i Prawo 9(847): 36-53.

Dębska, H., Warczok T. (2018). Sakralizacja i profanacja. Trybunał Konstytucyjny jako struktura mityczna. Państwo i Prawo 73(5): 63-74.

Dezaley, M., Garth, B. (1996). Dealing with Virtue: International Commercial Arbitration and the Construction of Transnational Leal Order. Chicago. 
Florczak-Wątor, M., Pach, M. (2018). Co wymaga zmiany w procedurze wyboru sędziów do Trybunału Konstytucyjnego w Polsce. Państwo i Prawo 73(5): 22-42.

Garlicki, L. (1987). Sądownictwo konstytucyjne w krajach Europy Środkowo-Wschodniej. Warszawa.

Garlicki, L. (2016). Komentarz do art. 194 ust. 1 Konstytucji RP, [w:] L. Garlicki, M. Zubik (red.), Tom 1: Konstytucja Rzeczypospolitej Polskiej. Komentarz. Warszawa.

Gromski, W. (2009). Legitymizacja sądów konstytucyjnych wobec władzy ustawodawczej. Przegląd Sejmowy 4(93): 11-23.

Janicki, M., Władyka, W. (2016). Wielka wymiana kadr według PiS. Polityka 23.05. 2016, <https:// www.polityka.pl/tygodnikpolityka/kraj/1662252,1,wielka-wymiana-kadr-wedlug-pis.read>.

Kaczyński, J. (2014). Bardzo potężne siły dążą do tego, żeby pola nie była tym czym mogłaby być. Trzeba się temu przeciwstawić. W Polityce 7.06.2014. <https://wpolityce.pl/polityka/199640-jaroslaw-kaczynski-dla-wpolitycepl-bardzo-potezne-sily-daza-do-tego-zeby-polska-nie-byla-tym-czym-moglaby-byc-trzeba-sie-temu-przeciwstawic-nasz-wywiad> [dostęp: 14.02.2019].

Kantar Public (dawniej zespół badań społecznych TNS Polska) (2016). Zaufanie do instytucji publicznych. Porównanie lat 2006, 2011, 2016. <http://www.tnsglobal.pl/archiwumraportow/ files/2016/11/K.068_Zaufanie_do_instytucji_O10a-16.pdf $>$.

Krajewski, R. (2007). Leksykon instytucji wymiaru sprawiedliwości. Warszawa.

Le Roux, B., Bienaise S., Durand, J.-L (2019). Combinatorial Inference in Geometric Data Analysis. Boca Raton: Chapman and Hall/CRC.

Le Roux, B., Rounet H. (2010). Multiple Correspondence Analysis. Thousand Oaks.

Lebaron, F. (2000). The space of economic neutrality: types of legitimacy and trajectories of central bank managers. International Journal of Contemporary Sociology 37(2): 208-229.

Lebaron, F. (2006). Do central bankers biography matters? Sociologica 2: 1-37.

Lebaron, F. (2008). Central bankers in the contemporary global field of power: a 'social space' approach. Sociological Review 56: 121-144.

Lebaron, F. (2012), A universal paradigm for central bankers. An Inquiry based on Biographical Data. Social Glance 1(1): 40-58.

Łętowska, E., Wiewiórowska-Domagalska, A. (2018). A „good” change in the Polish Constitutional Tribunal? Osteuropa Recht 1: 79-93.

Młynarska-Sobaczewska, A. (2018). Wybór sędziów konstytucyjnych jako element legitymizacji sądu konstytucyjnego. Państwo i Prawo 73(5): 43-62.

O co chodzi w PiS-owskiej nowelizacji ustawy o Sądzie Najwyższym, luc. Gazeta Wyborcza, 19.07. 2018. <http://wyborcza.pl/7,75398,23692809,o-co-chodzi-w-pis-wskiej-nowelizacji-ustawy-o-sadzie-najwyzszym.html> [dostęp: 14.02.2019].

Ranking kierunków studiów Perspektywy. Prawo 2018 (2018). Perpektywy.pl <http://www.perspektywy.pl/RSW2018/ranking-kierunkow-studiow/kierunki-spoleczne/prawo), uzupełnionym> [dostęp: 14.02.2019].

Safjan, M. (2016). Polityka a Trybunał Konstytucyjny. Ruch Prawniczy, Ekonomiczny i Socjologiczny 78(1): 35-42.

Siedlecka, E. (2006a). Wybór sędziów do TK był czysto polityczny. Gazeta Wyborcza 27.10.2006, [dostęp: 14.02.2018].

Siedlecka, E. (2006b). Trybunał z łapanki. Gazeta Wyborcza. <http://wyborcza.pl/1,75248,3783073. html> 11.12.2006 [dostęp: 14.02.2018].

Siedlecka, E. (2018a). Sądy będzie gorzej. Polityka 13.08.2018, [dostęp: 14.02.2019].

Siedlecka, E. (2018b). PiS-wymiana sędziów. Wszyscy będziemy gorszego sortu. Polityka 20.08.2018 [dostęp: 14.02. 2019]. <https://www.polityka.pl/tygodnikpolityka/kraj/1760696,1,pis-wymienia-sedziow-wszyscy-bedziemy-gorszego-sortu.read> [dostęp: 14.02.2019].

Skapska G., Bryda, G. (2013). Apolityczność czy sprawiedliwość proceduralna? Zaufanie do sądowego wymiaru sprawiedliwości na tle innych instytucji publicznych w Polsce. Studia Socjologiczne 1(208): 77-94.

Sondaż: Wzrosło zaufanie do sądów i UE, spadło do Kościoła (2020). Rzeczpospolita 28.01.2020, <https://www.rp.pl/Spoleczenstwo/301279913-Sondaz-Wzroslo-zaufanie-do-sadow-i-UE-spadlo-do-Kosciola.html>. 
Warczok, T. (2013). Konstruktywny spór filozofii i socjologii w projekcie teoretycznym Pierre'a Bourdieu. Przegląd Filozoficzny. Nowa seria 22. 3(87): 43-58.

Weber, M. (2002). Gospodarka i społeczeństwo. Zarys socjologii rozumiejącej. Warszawa.

Wojciechowska, R. (2014). Jarosław Kaczyński w Gdańsku: w Polsce musi nastapić wymiana elit, Dziennik Bałtycki. 24.08.2014. <https://dziennikbaltycki.pl/jaroslaw-kaczynski-w-gdansku-w-polsce-musi-nastapic-wymiana-elit-zdjecia-wideo/ga/3552847/zd/4154787> [dostęp: 14.02.2019].

Zajadło, J. (2009). Wewnętrzna legitymizacja sądu konstytucyjnego. Przegląd Sejmowy 4(93): $129-144$.

Zajadło, J., Koncewicz, T. (2015). Jak nie wybierać sędziów do Trybunału Konstytucyjnego. Gazeta Wyborcza, 24.06.2015 <http://wyborcza.pl/1,75968,18188072,Jak_nie_wybierac_sedziow_ Trybunalu_Konstytucyjnego.html> [dostęp: 14.02.2018].

Zoll, A. (2016). Sposób wyboru sędziów Trybunału Konstytucyjnego. Ruch Prawniczy, Ekonomiczny i Socjologiczny 78(1): 43-50.

\section{THE LEGITIMIZATION OF THE CONSTITUTIONAL TRIBUNAL: A RELATIONAL APPROACH}

\section{S u m m a r y}

The aim of this article is to demonstrate the process of the legitimization of the Polish Constitutional Tribunal. In contrast to the dominant legal perspective, we consider the Tribunal relationally, as a kind of social space, located at the intersection of several social worlds that influence it (law, science, politics, and administration). The study concerns the biographies of all the judges elected from 1985 to 2018. Judges are treated as holders of various types of resources-capital (academic title, legal profession, government function, parliamentary mandate, etc.). The study, conducted by means of multiple correspondence analysis, allowed us to reconstruct the Constitutional Tribunal's space. As a consequence, we have revealed not only the complexity and multidimensionality of the legitimacy of the Polish Constitutional Tribunal, but also captured its dynamic.

Keywords: Constitutional Tribunal; judges; legitimization; multiple correspondence analysis; relationality 